\title{
Flash-flood potential assessment and mapping by integrating the weights-of-evidence and frequency ratio statistical methods in GIS environment - case study: Bâsca Chiojdului River catchment (Romania)
}

\author{
Romulus Costache ${ }^{1,2, *}$ and Liliana Zaharia ${ }^{1}$ \\ ${ }^{1}$ Department of Geography, University of Bucharest, 1, Nicolae Bălcescu Boulevard, \\ 050107 Bucharest, Romania. \\ ${ }^{2}$ National Institute of Hydrology and Water Management, Șos. București-Ploiești 97, Sector 1, \\ Bucharest, Romania. \\ *Corresponding author. e-mail: romuluscostache2000@yahoo.com
}

MS received 17 October 2016; revised 17 January 2017; accepted 18 January 2017; published online 16 June 2017

Given the significant worldwide human and economic losses caused due to floods annually, reducing the negative consequences of these hazards is a major concern in development strategies at different spatial scales. A basic step in flood risk management is identifying areas susceptible to flood occurrences. This paper proposes a methodology allowing the identification of areas with high potential of accelerated surface run-off and consequently, of flash-flood occurrences. The methodology involves assessment and mapping in GIS environment of flash flood potential index (FFPI), by integrating two statistical methods: frequency ratio and weights-of-evidence. The methodology was applied for Bâsca Chiojdului River catchment $\left(340 \mathrm{~km}^{2}\right)$, located in the Carpathians Curvature region (Romania). Firstly, the areas with torrential phenomena were identified and the main factors controlling the surface run-off were selected (in this study nine geographical factors were considered). Based on the features of the considered factors, many classes were set for each of them. In the next step, the weights of each class/category of the considered factors were determined, by identifying their spatial relationships with the presence or absence of torrential phenomena. Finally, the weights for each class/category of geographical factors were summarized in GIS, resulting the FFPI values for each of the two statistical methods. These values were divided into five classes of intensity and were mapped. The final results were used to estimate the flash-flood potential and also to identify the most susceptible areas to this phenomenon. Thus, the high and very high values of FFPI characterize more than one-third of the study catchment. The result validation was performed by (i) quantifying the rate of the number of pixels corresponding to the torrential phenomena considered for the study (training area) and for the results' testing (validating area) and (ii) plotting the ROC (receiver operating characteristics) curve.

Keywords. FFPI; weights-of-evidence; frequency ratio; GIS; Bâsca Chiojdului River; run-off; flashflood; ArcGIS.

\section{Introduction}

In the last few decades, climate change and related impacts such as floods have generated significant worldwide negative consequences on both natural and human systems. The recent detection of increasing trends in extreme precipitation and discharge in certain catchments implies greater flood 
risks at regional scale (IPCC 2014). The large damages generated annually by floods reveal the high vulnerability and exposure of many regions to this widespread and frequent hazard. Thus, many research studies from the international literature is focused on the assessment of flash-flood exposure and vulnerability (Ruin et al. 2008; Fuchs 2009; Špitalar et al. 2014; Fuchs et al. 2015; Terti et al. 2015; Karagiorgos et al. 2016a, b). In this context, flood risk mitigation continues to be a real challenge for water management and territorial development policies. In accordance with the 2007/60/EC directive on the assessment and management of flood risks, an elementary step in flood risk management consists of flood risk and hazard mapping. To this end, GIS-based spatial analysis techniques are particularly useful. Among other benefits, these techniques allow the identification of areas that are susceptible to accelerated run-off and implicitly, to flash-floods occurrence/susceptibility mainly caused by heavy rainfall. Areas with high susceptibility to flash-flood occurrences, due to heavy rainfall, are generally characterized by the presence of several geographical factors (steep slopes, impervious surfaces, high density of hydrographical network, deforested surfaces) which favour the accelerated surface run-off and further the water convergence into the main river channels and flood wave propagation from the upper area of the basin to the lower zone (Costache et al. 2014). For more accurate results, integrating statistical methods in spatial analyses is suitable.

In this context, this paper aims to propose a methodology for flash-flood potential assessment and mapping, based on the integration in GIS environment of run-off's main control factors and two statistical analysis methods, in order to identify areas with very high susceptibility to flash-flood occurrence. One of the methods previously used in scientific literature for estimating the accelerated run-off potential was based on determining the flash-flood potential index (FFPI). This index was developed for the first time by Greg Smith (2003) for Colorado river basin, in the National Weather Service (USA). At that moment, FFPI was considered as an additional tool for Flash-Flood Monitoring Prediction Advanced (FFMPA), used in order to improve the quality of flash-flood forecasts. Four geographical variables (slope, vegetation, soil type and land use) were taken into account and overlaid in GIS environment, by the author, in order to calculate the FFPI values across the Colorado river basin. In the National Weather Service, other studies regarding FFPI were carried out for different areas of USA by authors like Kruzdlo (2010), Ceru (2012), Zogg and Deitsch (2013), Arachchige and Perera (2015), the methodology being improved by considering a higher number of geographical variables and by weighing these factors into the final equation of FFPI. In Romania, many studies focussing on the determination of FFPI for several regions were carried out by authors like Teodor and Matreata (2011), Zaharia et al. (2012), Minea (2013), Prăvălie and Costache (2014). One of the limitations of FFPI is not taking into account the temporal variability of soil moisture, which is one of the most important factors that influences the surface run-off characteristics. In an attempt to improve the results prompted by the FFPI-based method, this paper, proposes the integration of two of the most widely used spatial statistical methods for identifying areas that are susceptible to hazards: i.e., weights-of-evidence (Lee and Choi 2004; Dahal et al. 2008; Regmi et al. 2010; Kayastha et al. 2012) and frequency ratio (Lee and Sambath 2006; Lee and Pradhan 2007; Yilmaz 2009; Yalcin et al. 2011). Formerly, these methods have mainly been used in studies aiming to identify areas susceptible to landslides (Corsini et al. 2009; Poudyal et al. 2010; Pradhan et al. 2010; Mohammady et al. 2012; Park et al. 2013; Pourghasemi et al. 2013). In this paper, the results for each statistical methods were validated in two different ways: (i) by quantifying the distribution weight for the number of pixels corresponding to torrential phenomena considered both for the study (training area) and for results' testing (validating area), and (ii) by using the ROC (receiver operating characteristics) curve (Mărgărint et al. 2013).

The proposed methodology can be useful for identifying the areas susceptible to flash-floods in catchments for which there are no maps/ information on flood hazard. In areas where high susceptibility to flash-floods are identified, a more in-depth investigation can be conducted, based on hydraulic models that allow flood-prone area delineation and flood risk mapping (Costache et al. 2015; Zaharia et al. 2015). Given the fact that flash-floods are one of the most damaging natural disasters at planetary scale (Youssef et al. 2011), the identification of the areas with very high flash-flood potential plays a crucial role mainly for adopting the best measures in order to reduce flash-floods peak discharge, as well as for increasing flash-flood forecasts accuracy. From the 
most appropriate measures which can be taken, we can mention: afforestation activities, torrent planning and slopes terracing.

Mapped information on flood hazard and related risks is essential for diminishing the flood-induced losses. The cartographic products are very useful for helping decision makers and map users from various fields (such as strategic planning, emergency management or the public) to adopt appropriate actions and measures for flood risk mitigation (Meyer et al. 2012; Godfrey et al. 2015; Gonçalves et al. 2015). But it is important that the hazard or risk maps design fulfil the requirement to serve as an efficient communication tool both for specialists/practitioners and laypeople (Fuchs et al. 2009).

\section{Study area}

The study area corresponds to the Bâsca Chiojdului River catchment, located in the central south-eastern part of Romania (figure 1), in the Carpathians' curvature region. The catchment area is $340 \mathrm{~km}^{2}$, of which $44 \%$ overlaps the Carpathian (mountainous) region, and $56 \%$ the Subcarpathian (hilly) region. The relatively small size of the catchment, and especially of its sub-catchments, is a

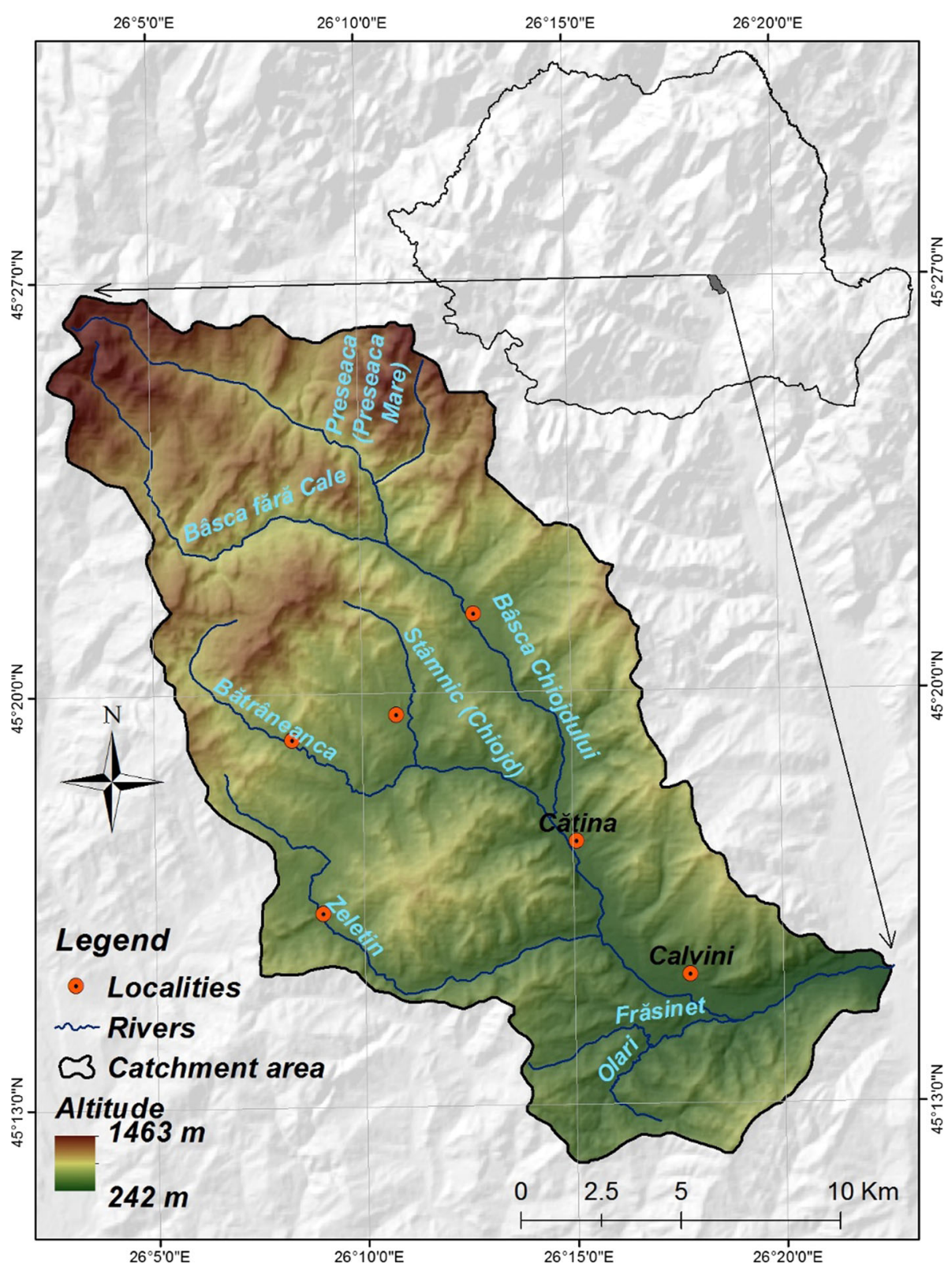

Figure 1. Bâsca Chiojdului River catchment and its location in Romania. 
factor favouring flash-flood occurrence. The catchment elevation ranges from 242 to $1463 \mathrm{~m}$ asl. It has an average altitude of $656 \mathrm{~m}$ asl and an average slope of approximately $12.3^{\circ}$, features that also favour accelerated surface run-off and flood occurrence.

The catchment's shape, an important factor that influences the time of run-off concentration, is reflected by the circularity ratio $\left(R_{c}\right)$, computed with the equation (Pişota et al. 2010):

$$
R_{c}=\frac{4 \pi A}{P^{2}},
$$

where $A$ is the catchment area $\left(\mathrm{km}^{2}\right)$, and $P$ is the catchment perimeter $(\mathrm{km})$.

The circularity ratio of the whole Bâsca Chiojdului catchment is 0.46 , while for the catchments of the main tributaries, $R_{c}$ ranges from 0.36 , in the Zeletin catchment, to 0.63 in the Preseasca catchment (table 1). The higher the circularity ratio, the lower the catchment area, and the steeper the slopes are, the shorter the water concentration time in the catchment is. For the study area, the concentration time ranges from $1.34 \mathrm{hrs}$ in the Olari catchment, to 7.27 hrs for the overall Bâsca Chiojdului catchment (table 1). The concentration time was determined with the following equation (DHI 2009):

$$
T \operatorname{lag}=\frac{\left(L \times 3.28 \times 10^{3}\right)^{0.8} \times\left(\frac{1000}{C N_{a w}}-9\right)^{0.7}}{1900 \times Y^{0.5}}
$$

and

$$
T_{c}=\frac{T \operatorname{lag}}{0.6}
$$

where Tlag is the lag time (hr); $L$ is the hydraulic length of the catchment $(\mathrm{km}) ; C N_{a w}$ is the average curve number within the catchment area; $Y$ is the average catchment slope $\%$; and $T_{c}$ is the concentration time (hr).

Other characteristics of the Bâsca Chiojdului River catchment and its sub-catchments that influence run-off and streamflow, are listed in table 1.

The forest cover is another important geographic factor controlling the run-off. The afforestation ratio within Bâsca Chiojdului River catchment is $50 \%$. In terms of sub-catchments, the forest rate ranges from 23\%, in Stâmnic River catchment, to $90 \%$ in the Preseasca River catchment (table 1). Another important runoff control variable is the

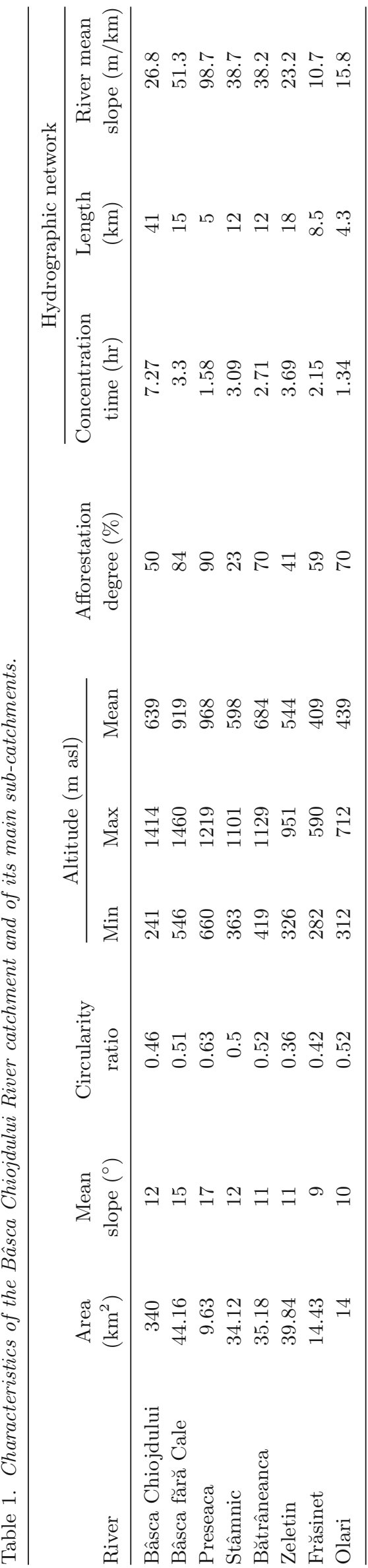


hydrologic soil group (Chendeş 2011; Costache 2014). In the study catchment, soil group B (with predominantly loamy texture, and hydraulic conductivity ranging from 10 to $40 \mu \mathrm{m} / \mathrm{s}$, according to the National Engineering Handbook 2007) is the most extensive ( $41 \%$ of the catchment's area). It is followed by soil group C (having loamyclayey textured soils, with a hydraulic conductivity that ranges between 1 and $10 \mu \mathrm{m} / \mathrm{s}$ ), which covers $33 \%$ of the catchment's area, and by soil group D (with predominantly clayey texture, and hydraulic conductivity below $1 \mu \mathrm{m} / \mathrm{s}$ ), which totals $22.2 \%$. The hydrologic group that is the most restrictive for run-off is A (predominantly sandy textured soils with hydraulic conductivity over $40 \mu \mathrm{m} / \mathrm{s}$ ), which is spread on $3 \%$ of the study catchment.

Bâsca Chiojdului River is $41 \mathrm{~km}$ long, and flows into Buzau River. Its main tributaries are generally short (they range between 4.3 and $18 \mathrm{~km}$ in length) and have steep slopes that range from 10.7 to 98.7 $\mathrm{m} / \mathrm{km}$ (table 1), features favouring the flash-flood propagation speed.

Inside the study area, there is only one gauging station, on the Bâsca Chiojdului River, at Chiojdu. It is part of the monitoring network of the 'Romanian Waters' National Administration, and controls an area of $105 \mathrm{~km}^{2}$ (approximately one third of the catchment's total area that, for the most part, overlaps the mountainous sector) with a mean altitude of $906 \mathrm{~m}$.

The average multiannual discharge of Bâsca Chiojdului River at the aforementioned station is $1.21 \mathrm{~m}^{3} / \mathrm{s}$ (for the period 1961-2012). During the most severe flash-floods, the maximum discharge exceeded $100 \mathrm{~m}^{3} / \mathrm{s}: 300 \mathrm{~m}^{3} / \mathrm{s}$ in $1975,268 \mathrm{~m}^{3} / \mathrm{s}$ in 1991 and $236 \mathrm{~m}^{3} / \mathrm{s}$ in 2005 (figure 2) (according to NIHWM data). The trendline analysis shows a slight decrease of the maximum annual discharge between 1964 and 2012 (figure 2), but it is not statistically significant.

Due to the catchment's geographical features, the floods are generally fast, with a short time to peak. Thus, during the largest flood recorded in the Bâsca Chiojdului River catchment in July 1975, the discharge increased from 1.02 to $300 \mathrm{~m}^{3} / \mathrm{s}$ in only $9 \mathrm{hrs}$; in 1990 the discharge increased from 1.34 to $170 \mathrm{~m}^{3} / \mathrm{s}$ in $5 \mathrm{hrs}$, and in 2005, the discharge increased from 2.52 to $236 \mathrm{~m}^{3} / \mathrm{s}$ in $11 \mathrm{hrs}$ (NIHWM 2015).

Flash-floods and torrential run-off affect people and social-economic elements in the settlements of the study area, namely Chiojdu, Starchiojd, Cătina, Calvini, Poseștii-Pământeni and Bătrâni (figure 1). These are rural settlements, with predominantly agricultural (mostly livestock-related) and forestry activities. Infrastructure and transport elements, such as County roads 102 B, 102 $\mathrm{L}$ and, in part, $100 \mathrm{M}$, are also exposed to these hazards.

\section{Data and methodology}

The study is based mostly on spatial data, i.e., hypsometry, geology, soils, land use/cover data acquired from different sources that are mentioned below.

The methodology consists of three steps.

The first step consisted of identifying and mapping areas affected by torrentiality in the

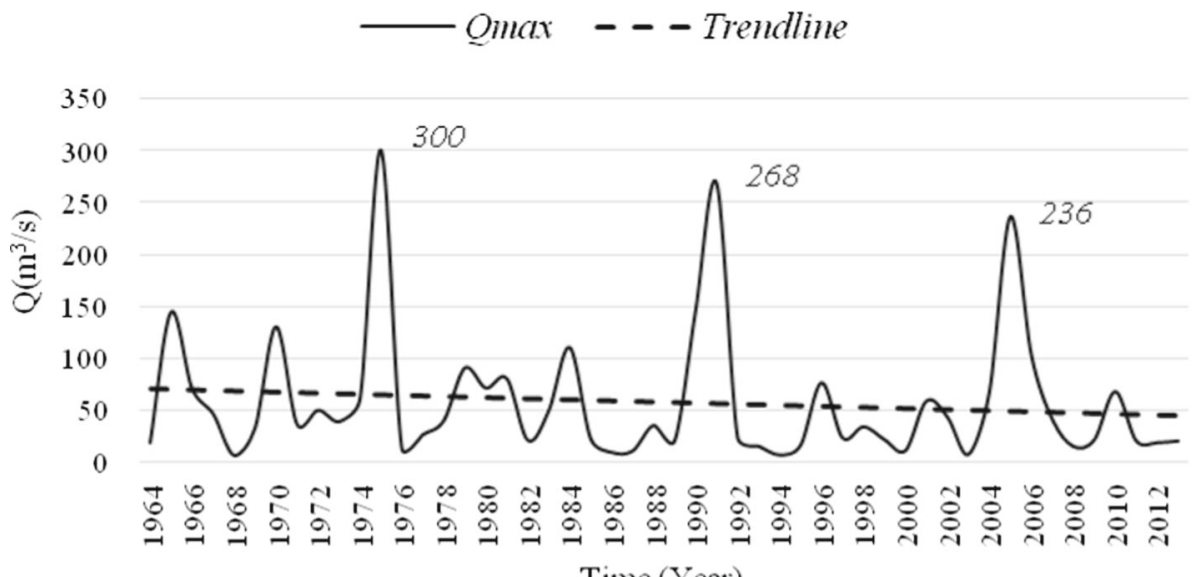

Figure 2. The maximum annual discharge (Qmax) variation of Bâsca Chiojdului River, at Chiojdu gauging station (1964-2012). 
Bâsca Chiojdului River catchment, based on Orthophotomaps, with $2 \mathrm{~m}$ resolution, edited by NACLR in 2008. The areas affected by torrential phenomena are characterized by the unified presence of torrential microform of relief such as ravines and gullies which are generated by surface runoff. Due to the fact that flash-floods are generated on surfaces with high slopes and a low density of forest vegetation, these areas are favourable to surface run-off generation, phenomenon that precedes the flash-floods occurrence. In order to represent the spatial distribution of the surfaces with a high torrential degree, based on Orthophotomap observations, the areas characterized by the unitary presence of torrential specific relief microforms, resulting from water erosion, were identified. In order to be used in GIS environment, these areas were digitized. The areas identified as affected by these processes totalize approximately $34 \mathrm{~km}^{2}$, which corresponds to $\sim 10 \%$ of the study catchment area. Seventy percent of the $34 \mathrm{~km}^{2}$ were used for the assessment and mapping of flash-

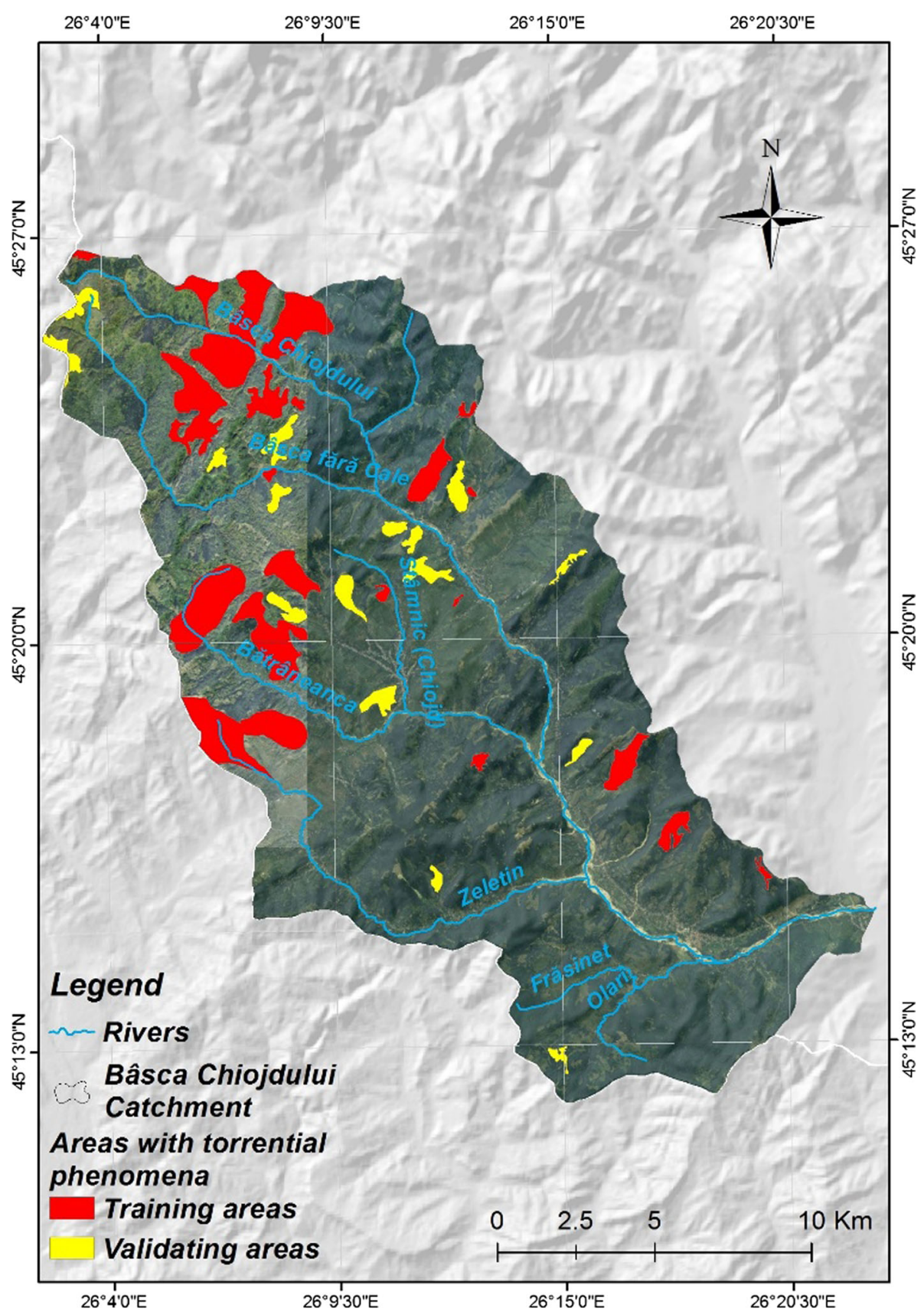

Figure 3. The spatial distribution of the areas with torrential phenomena within Bâsca Chiojdului River catchment. 
flood occurrence potential (training area), while $30 \%$ was considered for the result validation (validating area) (figure 3). In order to apply the statistical methods (weights-of-evidence and frequency ratio), the polygons designating torrentiality phenomena were converted in raster format with $20 \mathrm{~m}$ cell size.

The second step of the study consisted of selecting the geographic control factors/variables that influence the surface run-off, and processing them in GIS format. Based on the outcome, the Flash-Flood Potential Index (FFPI) values were computed and mapped. Comparing to previous studies in which a number of up to five geographical variables were taken into account to calculate FFPI, this study considered nine variables in order to increase the degree of accuracy and confidence of the final results: terrain slope, $\mathrm{L}-\mathrm{S}$ factor, profile curvature, drainage network density, hydrographic network convergence index, slope aspect, lithology, land use/cover and hydrologic soil groups (figures $4 \mathrm{a}, \mathrm{b}$ and 5 ).

The terrain slope, L-S factor, profile curvature, drainage network density and slope aspect were derived from the Digital Elevation Model (DEM) with $20 \mathrm{~m}$ cells, obtained by interpolating the level curves with equidistance of $5 \mathrm{~m}$, digitized after the Romania's topographic map 1:25,000.

The remaining three factors were initially obtained in polygon vector format: land use/cover was accessed from the European Corine Land Cover database (2006); lithology data was extracted from the Geological Map of Romania, 1:200,000; the hydrologic soil groups were identified based on soil textures, digitally processed from the soil map of Romania, 1:200,000 (SRIPA 2002). The factors initially derived in polygon format were converted in raster format with $20 \mathrm{~m}$ cell size so that they match the factors that were derived directly in raster format.

Based on the features of the considered variables, many classes were set for each factor. Thus, five classes of values were established for terrain slope, based on existing classifications in specialized literature on accelerated run-off (Fontanine and Costache 2013; Prăvălie and Costache 2014; Zaharia et al. 2015); the soil classes were clustered depending on the hydrologic groups they belonged to the land use types were grouped based on Manning coefficient values, which influence the surface run-off; the lithology was classified based on the rocks hardness (the hardest rocks favour the run-off); the profile curvature values were grouped in order to obtain different intervals for convex, concave and quasi-horizontal areas; the slope aspect was divided into five categories depending on sunlight exposure; the convergence index values were grouped, similarly to landform slope, into five classes, based on existing classifications found in specialized literature (Fontanine and Costache 2013; Prăvălie and Costache 2013; Costache et al. 2015); L-S factor and hydrographic network density values were classified by means of the Natural Breaks statistical method (Kumar and Anbalagan 2015). All geographical factors mentioned were mapped taking into account their classes or categories.

Regarding the distribution of training and validating areas in terms of topographic variables, the following situation is remarkable: the presence of more than $80 \%$ of these areas on slopes exceeding $15^{\circ}$; over $87 \%$ from the training and validating areas are found on surfaces with rare vegetation, while the soils from the hydrological group $\mathrm{C}$ are covered with $60 \%$ from the total surfaces affected by torrential phenomena, the same percentage belonging to slopes with southern, south-eastern and western exposure; relatively equal percentage $(20 \%)$ of the total area with torrential phenomena are specific for each class of drainage density and convergence index values; the areas with $\mathrm{L}-\mathrm{S}$ factor values between 3.75 and 10.76 are covered with $70 \%$ of torrential areas, while the surfaces with negative values of profile curvature contain a percentage of $90 \%$ from the areas with torrential phenomena; regarding the lithology, majority of the training and validating areas are located on rock types such as: flysch with alternate sandstone shale, gypsum, clays and sandstones.

The third step consisted of computing and mapping the FFPI by integrating the weights-ofevidence and frequency ratio statistical methods. The statistical computations are based on the number of pixels in the raster derived for the analysis.

The weights-of-evidence (WoE) method is a bivariate Bayesian statistical model that is widely used in order to determine susceptibility to landslides. This paper uses this method for the assessment of flash-flood potential. It is based on computing the weights that the nine considered factors have in-accelerated surface run-off and flash-flood occurrence. The weights of each factor classes/ categories were estimated based on the presence or absence of the phenomenon (torrentiality) inside the classes/categories. The model supposes the fact that factors favouring accelerated run-off are 

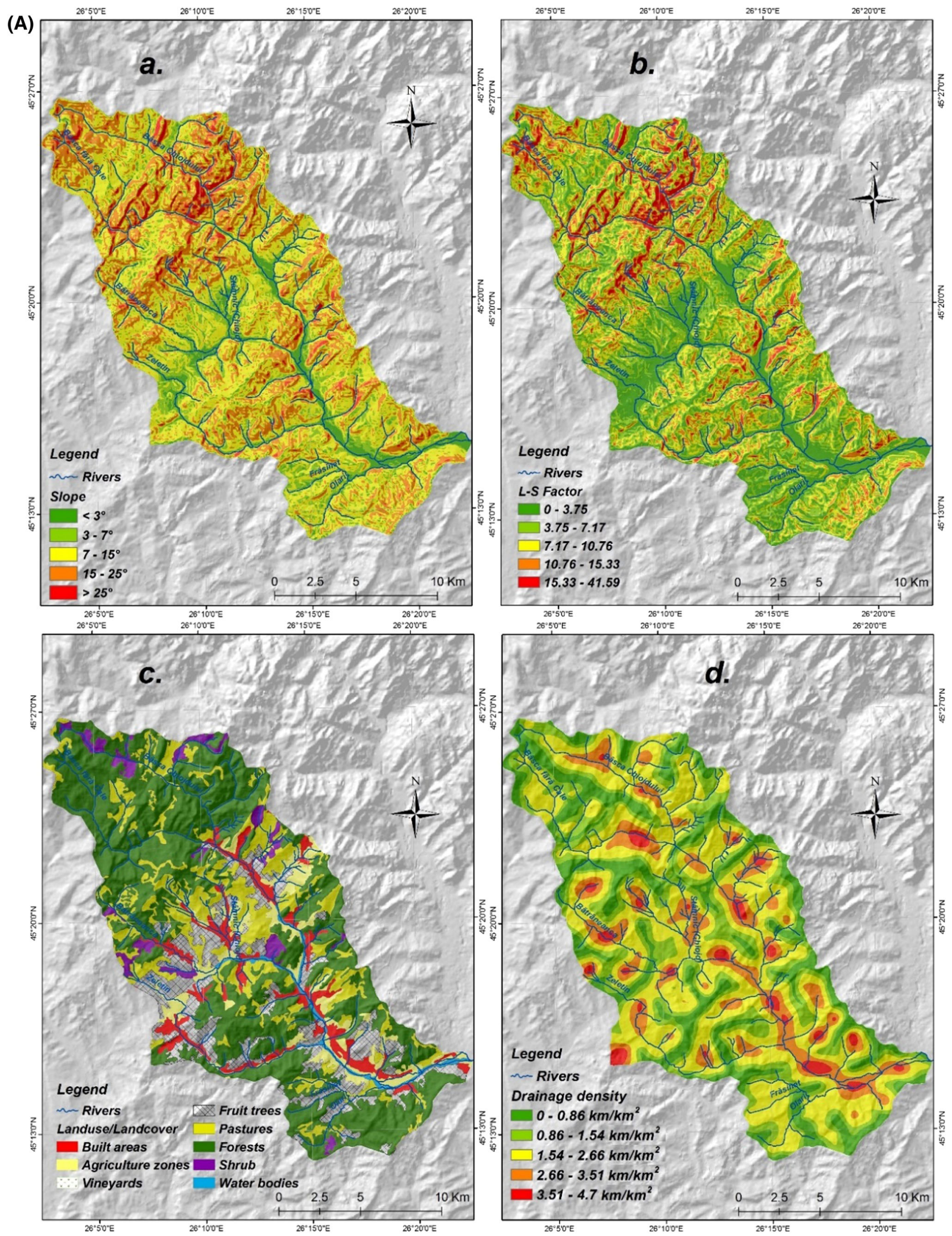

Figure 4(A). Run-off control factors in Bâsca Chiojdului River catchment: (a) Terrain slope; (b) L-S factor; (c) land use/land cover; and (d) drainage density. 



Figure 4(B). Run-off control factors in Bâsca Chiojdului River catchment: (a) profile curvature; (b) slope aspect; (c) hydrological soil groups; (d) convergence index. 


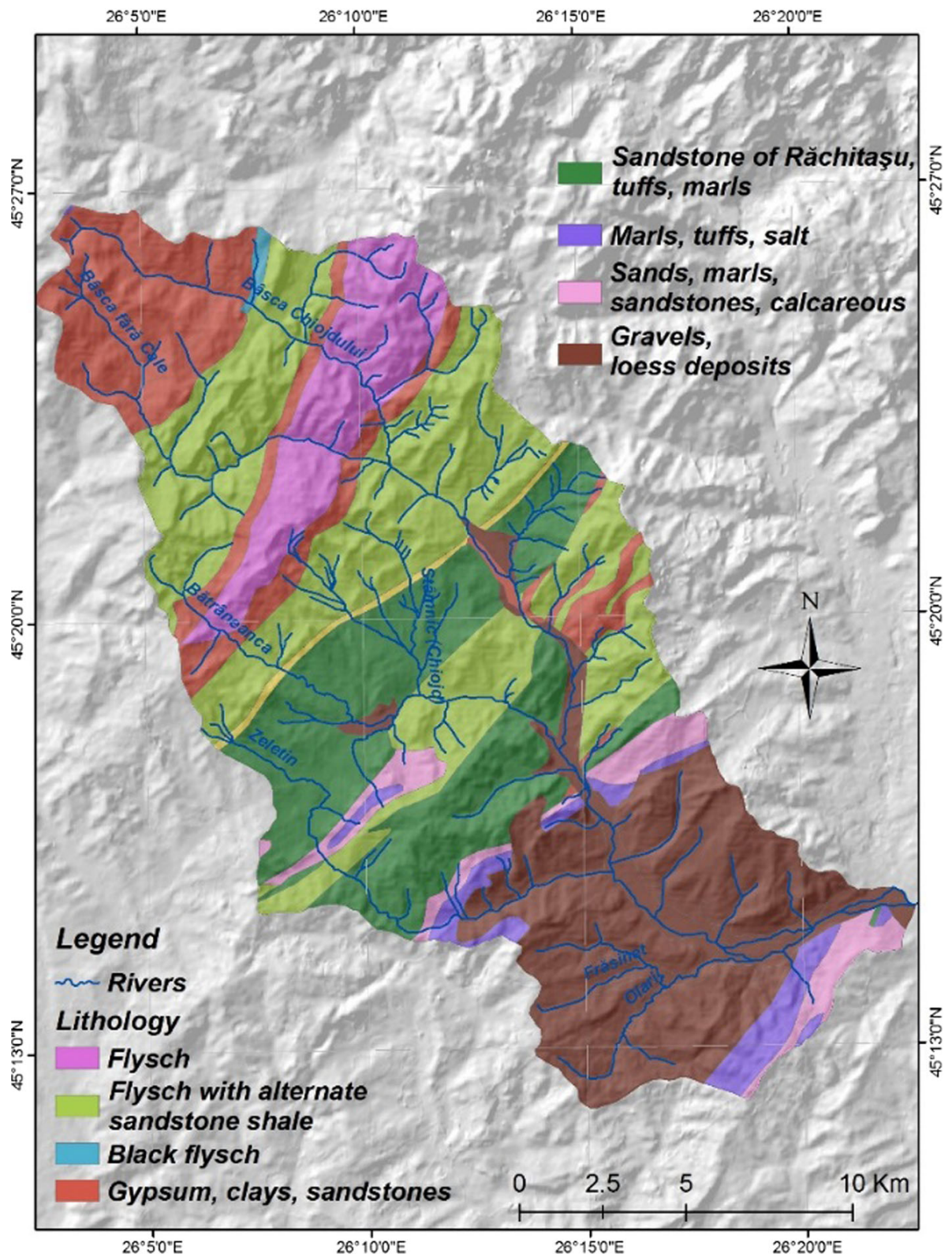

Figure 5. Lithological map of the Bâsca Chiojdului River catchment.

constant over time (Dahal et al. 2008). Determining each factor's weight firstly requires computing the positive weight $\left(W^{+}\right)$, which indicates a spatial association between a factor's class and the presence of the torrentiality phenomenon, and the negative weight $\left(W^{-}\right)$, which shows the absence of the spatial association between a factor's weight and the presence of the torrentiality phenomenon (Van Westen et al. 2003). The two types of weights are computed using the equation (Bonham-Carter 1994):

$$
W^{+}=\ln \frac{P\{B \mid S\}}{P\{B \mid \bar{S}\}}
$$

and

$$
W^{-}=\ln \frac{P\{\bar{B} \mid S\}}{P\{\bar{B} \mid \bar{S}\}}
$$

where $W^{+}$is the positive weight, $W^{-}$is the negative weight, $P$ is the probability, $B$ is the presence of run-off predictive factor, $\bar{B}$ is the absence of a run-off predictive factor, $S$ is the presence of torrentiality, and $\bar{S}$ is the absence of torrentiality.

The implementation of equations (4 and 5$)$ in GIS environment was possible by combining each class of the nine factors (which were reclassified depending on how their characteristics influence 
the surface run-off) with the areas where torrentiality phenomena are present. This operation was performed using the Combine tool of the ArcGIS 10.3.1 software at the raster pixels scale. Equations (4 and 5) can therefore be rewritten as (Van Westen et al. 2003):

$$
W^{+}=\ln \frac{N p i x_{1} /\left(N p i x_{1}+N p i x_{2}\right)}{N p i x_{3} /\left(N p i x_{3}+N p i x_{4}\right)}
$$

and

$$
W^{-}=\ln \frac{N p i x_{1} /\left(N p i x_{1}+N p i x_{2}\right)}{N p i x_{4} /\left(N p i x_{3}+N p i x_{4}\right)}
$$

where $N p i x_{1}$ is the number of pixels with torrentiality in the class; $N_{p i x_{2}}$ is the number of pixels with torrentiality from outside the class; $\mathrm{Npix}_{3}$ is the number of pixels in the class without torrentiality; $\mathrm{Npix}_{4}$ is the number of pixels without torrentiality from outside of the class; $W^{+}$is the positive weight and $W^{-}$is the negative weight.

The factors' final weighting (Wf) for computing the flash-flood potential was obtained with the formula (Van Westen 2002):

$$
W f=W \text { plus }+W \text { mintotal }-W \min ,
$$

where $W$ plus is the positive weight of a class factor, $W \min$ is the negative weight of a class factor, $W$ mintotal is the total of all negative weights in a multiclass map.

Finally, the Flash-Flood Potential Index $\left(\mathrm{FFPI}_{\mathrm{WoE}}\right)$ is given by the equation:

$$
\mathrm{FFPI}_{W o E}=\sum_{j=i}^{n} W f i j,
$$

where $W f i j$ is the final weight of class $i$ in parameter $j$ and $n$ is the numbers of variables.

The frequency ratio (FR) method. In order to assess the FFPI by integrating the frequency ratio method, the ratio between the number of pixels with torrentiality phenomena inside a factor's class and the total number of pixels with torrentiality phenomena over the whole study area was computed, using the equation (Lee and Pradhan 2007):

$$
F R=\frac{\left(N p(L X i) /\left(\sum_{i=1}^{m} N p(L X i)\right)\right)}{\left(N p(X j) /\left(\sum_{j=1}^{n} N p(X j)\right)\right)}
$$

where $F R$ is the frequency ratio of class $i$ of factor $j$; $N p(L X i)$ is the number of pixels with torrentiality within class $i$ of factor variable $X ; N p(X j)$ is the number of pixels within factor variable $X j ; m$ is the number of classes in the factor variable $X i ; n$ is the number of factors in the study area.

Once frequency ratios are computed for the classes of each factor influencing the surface runoff, the $\mathrm{FFPI}_{F R}$ was computed by adding the resulting values:

$$
\mathrm{FFPI}_{F R}=\sum_{j=i}^{n} F R
$$

where $F R$ is the frequency ratio of each class of factors taken into account for the analysis.

\section{Results}

\subsection{Weights-of-evidence method application}

Following the methodology described above, the class weights for the factors considered for assessing the FFPI through the weight-of-evidence (WoE) method were derived. Thus, for the terrain slope interval of $0-3^{\circ}$, the final weight $(W f)$ has a negative value of -1.34 . The highest value of the $W f$ (2.83) was assigned to the interval $>25^{\circ}$. To a certain extent, this value is also explained by the fact that the steeper the slopes are, the faster the runoff is. In terms of drainage density, the highest $W f$ value (0.37) is found in the interval 3.51-4.71 $\mathrm{km} / \mathrm{km}^{2}$. Slope aspect has the highest $W f$ values for slopes with SE, V (0.12) and S (0.07) exposure, while the lowest value is specific for shaded slopes with $\mathrm{N}$ and NE exposure (-0.4). For land use, $W f$ values increase from cover types with high Manning roughness coefficient, such as forest areas $(-2.36)$, to those with low Manning coefficient, such as built areas (2.18) (table 2). In terms of lithology, the $W f$ has low values $(-1.01)$ for sand, gravel and loess, and high values (1.82) for hard rocks (such as the Răchitașu sandstone), which favours surface runoff at the expense of infiltration.

The L-S factor behaves similar to the slope. Thus, the higher the factor's values are, the more the $W f$ increase (table 2). The convergence index has $W f$ values that range from -0.21 to 0.18 . Minimal values are specific for interfluve areas with positive values of the Convergence Index, while maximal values correspond to valley areas with high hydrographic network convergence. Due to the 
Table 2. Specific coefficients of $W o E\left(W^{+}, W^{-}, W f\right)$ and FR corresponding to factor classes considered for computing FFPI in the Bâsca Chiojdului catchment.

\begin{tabular}{|c|c|c|c|c|c|}
\hline Factor & Class & $\mathrm{W}^{+}$ & $\mathrm{W}^{-}$ & Wf & $\mathrm{FR}$ \\
\hline \multirow[t]{5}{*}{ Slope } & $0^{\circ}-3^{\circ}$ & -1.24 & 0.05 & -1.34 & 0.30 \\
\hline & $3^{\circ}-7^{\circ}$ & -0.01 & 0.00 & -0.11 & 0.99 \\
\hline & $7^{\circ}-15^{\circ}$ & 0.21 & -0.23 & 0.11 & 1.21 \\
\hline & $15^{\circ}-25^{\circ}$ & 1.19 & 0.07 & 1.09 & 1.43 \\
\hline & $>25^{\circ}$ & 1.53 & 0.01 & 2.83 & 2.10 \\
\hline \multirow{5}{*}{$\begin{array}{l}\text { Drainage density } \\
\left(\mathrm{km} / \mathrm{km}^{2}\right)\end{array}$} & $0-0.86$ & 0.07 & -0.02 & 0.08 & 1.06 \\
\hline & $0.86-1.54$ & -0.03 & 0.01 & -0.02 & 0.96 \\
\hline & $1.54-2.66$ & -0.33 & 0.10 & -0.32 & 0.73 \\
\hline & $2.66-3.51$ & 0.12 & -0.03 & 0.13 & 1.11 \\
\hline & $3.51-4.71$ & 0.36 & -0.05 & 0.37 & 1.38 \\
\hline \multirow[t]{5}{*}{ Aspect } & SV & 0.03 & 0.00 & 0.02 & 1.02 \\
\hline & $\mathrm{S}$ & 0.08 & -0.03 & 0.07 & 1.07 \\
\hline & SE, V & 0.13 & -0.05 & 0.12 & 1.13 \\
\hline & $\mathrm{E}, \mathrm{NV}$ & -0.10 & 0.03 & -0.11 & 0.90 \\
\hline & $\mathrm{N}, \mathrm{NE}$ & -0.39 & 0.04 & -0.4 & 0.69 \\
\hline \multirow[t]{5}{*}{ Landuse } & Forest & -2.63 & 0.40 & -2.63 & 0.56 \\
\hline & Fruit trees, shrubs & -0.45 & -0.05 & -0.45 & 1.16 \\
\hline & Agricole areas, Vineyards & 0.34 & 0.07 & 0.34 & 1.90 \\
\hline & Pastures & 1.28 & -0.49 & 1.28 & 2.94 \\
\hline & Built areas & 2.18 & 0.07 & 2.18 & 1.85 \\
\hline \multirow[t]{5}{*}{ Lithology } & Sands, Gravels, Loess & -0.94 & 0.04 & -1.01 & 0.41 \\
\hline & Marls, clay & -0.53 & 0.17 & -0.6 & 0.61 \\
\hline & Gypsum, Limestone & 0.27 & -0.20 & 0.2 & 1.27 \\
\hline & Sandstone, Tuffs, Schysts & 0.32 & -0.11 & 0.25 & 1.34 \\
\hline & Sandstone of Rachitașu & 1.75 & 0.03 & 1.82 & 2.19 \\
\hline \multirow[t]{5}{*}{ L-S factor } & $0-3.75$ & -0.41 & 0.09 & -0.45 & 0.68 \\
\hline & $3.75-7.17$ & -0.25 & -0.13 & -0.29 & 1.25 \\
\hline & $7.17-10.76$ & 0.15 & -0.06 & 0.11 & 1.14 \\
\hline & $10.76-15.33$ & 1.61 & 0.04 & 1.57 & 1.83 \\
\hline & $15.33-41.59$ & 2.39 & 0.02 & 2.35 & 2.69 \\
\hline \multirow[t]{5}{*}{ Convergence index } & 0-99 & -0.23 & 0.04 & -0.21 & 0.80 \\
\hline & $(-1)-0$ & -0.04 & 0.04 & -0.02 & 0.95 \\
\hline & $(-2)-(-1)$ & 0.10 & -0.01 & 0.12 & 1.09 \\
\hline & $(-3)-(-2)$ & 0.16 & -0.01 & 0.18 & 1.15 \\
\hline & $(-99)-(-3)$ & 0.16 & -0.04 & 0.18 & 1.15 \\
\hline \multirow[t]{4}{*}{ Hydrological soil groups } & A & 0.00 & 0.00 & 0.00 & 0.00 \\
\hline & B & -0.08 & 0.29 & -0.34 & 0.31 \\
\hline & $\mathrm{C}$ & 1.15 & 0.27 & 0.89 & 1.29 \\
\hline & $\mathrm{D}$ & 2.13 & -0.82 & 1.87 & 1.82 \\
\hline \multirow[t]{3}{*}{ Profil curvature } & $-2.8-0$ & -0.06 & 0.05 & -0.07 & 0.94 \\
\hline & $0-0.9$ & 0.05 & -0.06 & 0.04 & 1.04 \\
\hline & $0.9-2.4$ & -1.63 & 0.00 & -1.64 & 0.21 \\
\hline
\end{tabular}

WoE: Weights-of-evidence method; $\mathrm{W}^{+}$: positive weight; $\mathrm{W}^{-}$: negative weight; Wf: final weight; and FR: frequency ratio.

fact that torrentiality phenomena were not identified in the areas with soils belonging to the hydrologic group A, the WoE coefficients' value is zero. The highest $W f$ (1.87) is found in hydrologic group $\mathrm{D}$ (table 2). In terms of profile curvature, the highest $W f$ value (0.04) corresponds to the $0-0.9$ value class, and the lowest $(-1.64)$ to the $0.9-2.4$ class.
Once each factor class was weighted, the resulting weights were summed using the Raster Calculator function of the ArcGIS 10.3.1 software. Thus the $\mathrm{FFPI}_{W o E}$ values were obtained and mapped. These range from -8.82 to 3.89 , and were grouped into five classes. In order to classify them, four classification methods featured in the ArcGIS 10.3.1 
Table 3. Percent of the number of training and validating areas pixels in the FFPI WoE classes for different classification methods.

\begin{tabular}{|c|c|c|c|c|c|c|c|c|}
\hline \multirow{2}{*}{$\begin{array}{l}\text { Susceptibility } \\
\text { classes }\end{array}$} & \multicolumn{4}{|c|}{ Percent of training areas pixels } & \multicolumn{4}{|c|}{ Percent of validating areas pixels } \\
\hline & $\mathrm{NB}(\%)$ & $\mathrm{Q}(\%)$ & $\mathrm{EI}(\%)$ & $\mathrm{G}(\%)$ & $\mathrm{NB}(\%)$ & $\mathrm{Q}(\%)$ & $\mathrm{EI}(\%)$ & $\mathrm{G}(\%)$ \\
\hline 1. Very low & 0.35 & 3.97 & 0 & 0.03 & 0.17 & 3.75 & 0 & 0 \\
\hline 2. Low & 7.62 & 8.36 & 0.27 & 1.68 & 5.27 & 4.26 & 0.16 & 0.62 \\
\hline 3. Medium & 17.29 & 10.96 & 13.58 & 5.09 & 8.97 & 5.57 & 8.89 & 4.39 \\
\hline 4. High & 35.20 & 24.33 & 49.57 & 25.62 & 23.81 & 12.30 & 32.51 & 12.74 \\
\hline 5. Very high & 39.54 & 52.38 & 36.58 & 67.59 & 61.79 & 74.12 & 58.44 & 82.25 \\
\hline
\end{tabular}

NB: natural breaks; Q: quantile; EI: equal intervals; and G: geometrical interval.

were tested: natural breaks, quantile, equal intervals and geometric interval. For establishing the most appropriate classification method, the percentage distribution of the number of pixels with torrentiality phenomena areas used for computing WoE coefficients (training areas) and for validating results was identified for each value class (table 3 ). In the training area, most pixels are found in the fifth $\mathrm{FFPI}_{W o E}$ value class (very high) for the geometrical interval method $(67.59 \%)$, followed by quantile $(52.38 \%)$ and, with almost equal values, by natural breaks and equal intervals methods (39.54 and $36.58 \%$, respectively).

The same hierarchy resulted for the distribution of pixels used for validating results, with the mention that class percentage differences in all four classification cases are significant. Therefore, for the geometrical interval method, $82 \%$ of pixels are found in the fifth class with very high $\mathrm{FFPI}_{W o E}$ values, while the fourth class only totals $12.74 \%$ (table 3 ). The conclusion was that the most appropriate classification method for mapping $\mathrm{FFPI}_{W o E}$ values is the geometrical interval.

Therefore, considering the geometrical interval classification method, the first class of values, ranging from -8.82 to -3.63 , covers approximately $8 \%$ of the Bâsca Chiojdului River catchment and has a very low potential for accelerated run-off and flash-flood occurrence. These very low values are located especially along the large valleys of the study area, being characteristics for built-up areas from the following localities: Calvini, Pătârlagele and Cislău (figure 6). The class of low FFPI ${ }_{W o E}$ values, which corresponds to areas with low potential for accelerated run-off, ranges from -3.63 to -1.89 , and covers approximately $20 \%$ of the study area. These values are present especially in the southern part of the study area being present in Zeletin, Frăsinet and Olari catchments. The medium potential class, with $\mathrm{FFPI}_{W o E}$ values ranging from -1.89 to -0.49 , is spread relatively uniform throughout the Bâsca Chiojdului catchment, and totals approximately one third of its area. A quarter of the study area has high $\mathrm{FFPI}_{W o E}$ values (ranging between -0.49 and 1.14), which indicate a high potential for accelerated run-off and flood occurrence. Areas with high $\mathrm{FFPI}_{W o E}$ values are mainly located in the central and northern sectors of the Bâsca Chiojdului River catchment. The highest FFPI $_{W o E}$ values $(1.14-3.89)$, which indicate a very high potential for accelerated run-off and flood occurrence, cover approximately $15 \%$ of the total study area. They are mainly located in the upper zone of Stâmnic, Zeletin and Bătrâneanca catchments and also in the northern extremity of Bâsca Chiojdului River (figure 6). Very high and high FFPI values are characteristics for slopes located closely to the built-up area of Chiojdu, Starchiojd and Cătina localities.

\subsection{Frequency ratio method application}

By applying the frequency ratio $(F R)$ method as described in chapter $3, F R$ coefficients have resulted for the classes of the nine run-off control factors considered for computing the FFPI. Therefore, the highest $F R$ value (2.94) corresponds to the grassland areas of the land use factor. The same factor also includes the noteworthy cases of arable land, vineyards and built areas with high $F R$ values $\sim 1.9$ (table 2). Terrain slope values of over $25^{\circ}$ have an $F R$ coefficient of 2.10. For drainage network density, $F R$ values do not have a wide range: from 0.73 for the middle class to 1.38 for high density areas. The same type of slow variation was found for slope aspect and convergence index. The span between the lowest and the highest $F R$ values was 0.38 for slope exposure, and 0.35 for the convergence index (table 2). Higher $F R$ values resulted for areas with a hard lithologic substrate, 


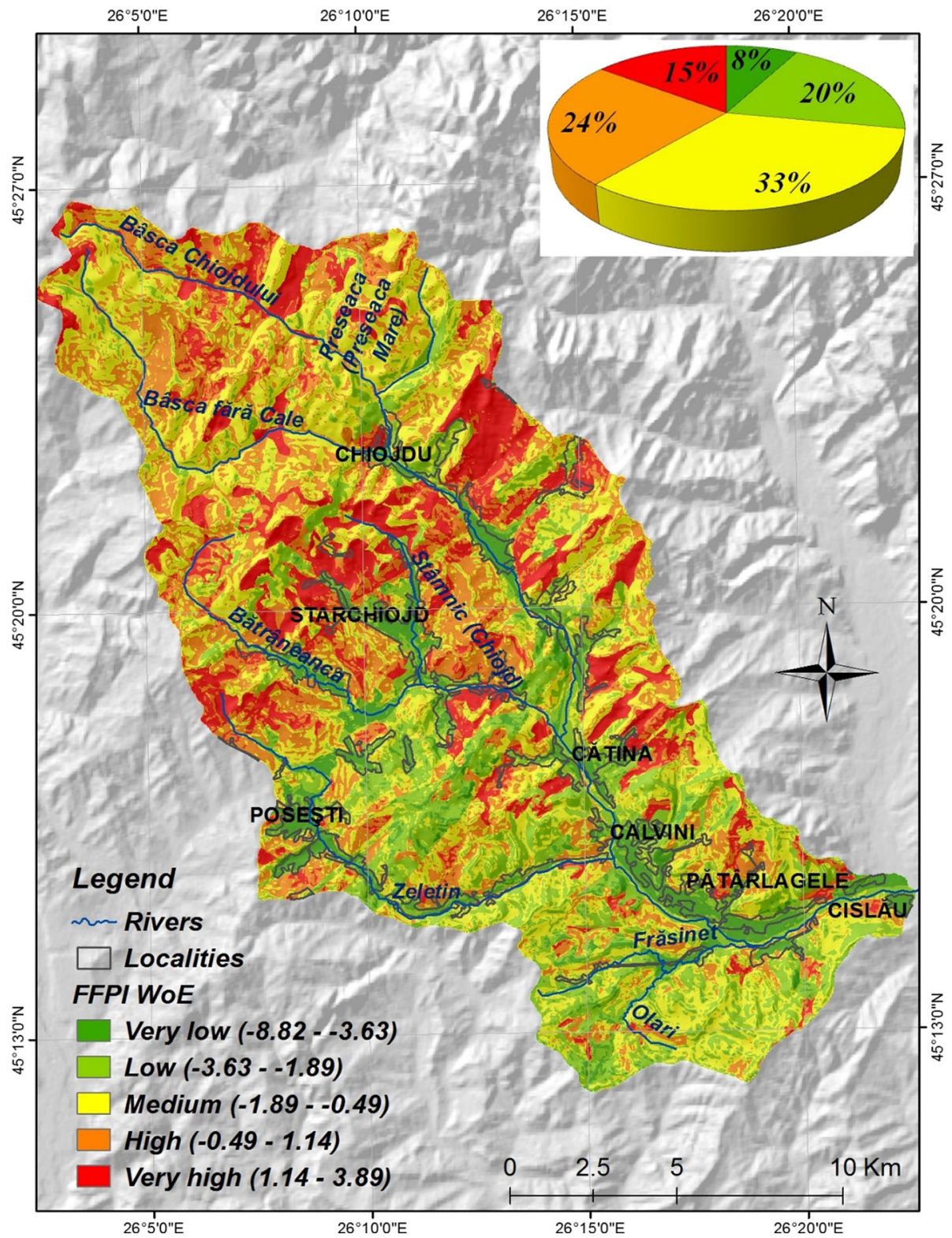

Figure 6. FFPI ${ }_{W o E}$ distribution in the Bâsca Chiojdului River catchment.

i.e., Răchitașu sandstone (2.19), for the fifth class of the L-S factor (2.69), and for hydrologic soil group D (1.82). In case of the profile curvature, $F R$ values ranged from 0.21 (for the $0.9-2.4$ interval) to 1.04 (for the 0-0.9 interval) (table 2 ). It should be noted that the values of $F R$ coefficients of the factors considered for determining the FFPI are distributed similarly to WoE coefficients computed for the classes of the same factors.

The mapping of the $\mathrm{FFPI}_{F R}$ values was similar to the mapping of the $\mathrm{FFPI}_{W o E}$ values. Cartographic algebra was therefore used for summing the nine geographic factors to which $F R$ values were attributed. The resulting $\mathrm{FFPI}_{F R}$ values for the Bâsca Chiojdului River catchment range from
4.68 to 12.68 , and were grouped into five classes of intensity.

The optimal classification method was chosen similarly to the WoE, after estimating the percentage of pixels with torrentiality phenomena present in each value class. As with $\mathrm{FFPI}_{F R}$, the highest pixel percentage of the fifth $\mathrm{FFPI}_{F R}$ value class (with torrentiality phenomena) used both for computing the $\mathrm{FFPI}_{F R}$ (training area) and for validating results (validating area), was obtained by applying the geometrical interval classification method. With this method, $58.65 \%$ of training area pixels were distributed in the very high $\mathrm{FFPI}_{F R}$ value class, followed by the quantile $(51.74 \%)$ and natural breaks $(34.5 \%)$ methods (table 4$)$. The 
Table 4. Percent of the number of training and validating areas pixels in the FFPI $I_{F}$ classes according to different classification methods.

\begin{tabular}{|c|c|c|c|c|c|c|c|c|}
\hline \multirow{2}{*}{$\begin{array}{c}\text { Susceptibility } \\
\text { classes }\end{array}$} & \multicolumn{4}{|c|}{ Percent of training areas pixels } & \multicolumn{4}{|c|}{ Percent of validating areas pixels } \\
\hline & $\mathrm{NB}(\%)$ & $\mathrm{Q}(\%)$ & $\mathrm{EI}(\%)$ & $\mathrm{G}(\%)$ & $\mathrm{NB}(\%)$ & $\mathrm{Q}(\%)$ & $\mathrm{EI}(\%)$ & $\mathrm{G}(\%)$ \\
\hline Very low & 0.45 & 2.75 & 0 & 1.11 & 0.31 & 2.88 & 0 & 0.86 \\
\hline Low & 7.85 & 8.70 & 1.69 & 9.63 & 6.69 & 5.57 & 1.56 & 7.30 \\
\hline Medium & 21.07 & 11.92 & 34.84 & 5.06 & 7.80 & 4.92 & 15.80 & 2.38 \\
\hline High & 36.13 & 24.89 & 37.34 & 25.54 & 17.10 & 8.23 & 34.50 & 8.92 \\
\hline Very high & 34.50 & 51.74 & 26.13 & 58.65 & 68.10 & 78.41 & 48.14 & 80.54 \\
\hline
\end{tabular}

NB: natural breaks; Q: quantile; EI: equal intervals; and G: geometrical intervals.

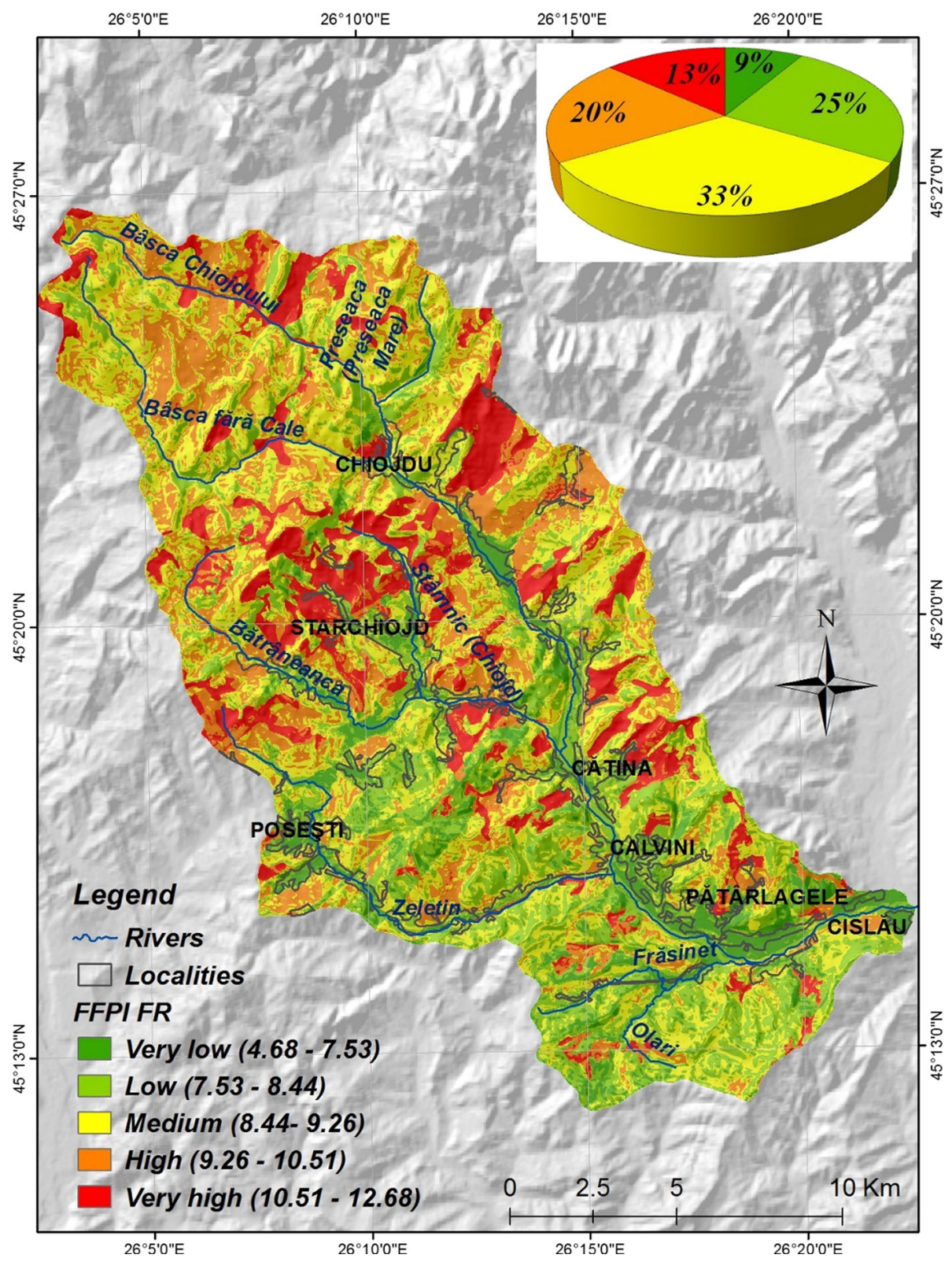

Figure 7. FFPI $F R$ distribution in the Bâsca Chiojdului River catchment. 
same hierarchy resulted for pixels corresponding to areas used to validate results (percentage differences between the very high class and the rest were significant in this instance as well).

FFPI $_{F R}$ values were grouped similarly to the FFPI $_{W o E}$ classification (geometrical interval method). The first value class ranges from 4.68 to 7.53 and indicates a very low potential of accelerated run-off. It is characteristic to the lower sectors of the main valleys in the Bâsca Chiojdului River catchment, and totals $9 \%$ of its area (which is close to the very low potential areas determined based on $\left.\mathrm{FFPI}_{W o E}\right)$. The second $\mathrm{FFPI}_{F R}$ value class ranges between 7.53 and 8.44, and indicates a low potential of accelerated run-off. This class totals a quarter of the catchment area, $5 \%$ more than the corresponding class of $\mathrm{FFPI}_{W o E}$. The average $\mathrm{FFPI}_{F R}$ value class (medium potential), ranging from 8.44 to 9.26, totals a third of the Bâsca Chiojdului River catchment, which equals the area of the similar FFPI $_{W o E}$ class. These values are spread relatively uniformly throughout the study area (figure 7).

The high $\mathrm{FFPI}_{F R}$ values (high potential), ranging from 9.26 to 10.51 , are mainly located in the central and northern sectors of the study catchment (figure 7 ), and total $20 \%$ of its area (3\% less than the corresponding FFPI ${ }_{W o E}$ class). The areas with a very high potential of accelerated run-off and flood occurrence have $\mathrm{FFPI}_{F R}$ values ranging from 10.51 to 12.68 (figure 7 ). They total $13 \%$ of the study area $\left(2 \%\right.$ less than the very high $\mathrm{FFPI}_{W o E}$ value class) and are characteristic of the central and northern parts of the Bâsca Chiojdului River catchment, being mainly located in the upper sectors of the Stâmnic, Bătrâneanca and Zeletin catchments.

\subsection{Validation of results}

The results obtained by using the two statistical methods for computing the FFPI were validated in two ways: (i) by quantifying the rate of the number of pixels corresponding to torrentiality phenomena considered for the study (training area) and for the results' testing (validating area) and (ii) by means of the ROC (receiver operating characteristics) curve.

In the former case, the results listed in tables 4 and 5 clearly indicate that most of the pixels corresponding to torrentiality phenomena areas are found in the classes with high and very high $\mathrm{FFPI}_{W o E}$ and $\mathrm{FFPI}_{F R}$ values, considering four classification methods for value intervals. Thus, for the $\mathrm{FFPI}_{W o E}$, the percentage of validating areas pixels in the very high class ranges between $58.44 \%$ (equal intervals method) and $82.25 \%$ (geometrical interval method). For the $\mathrm{FFPI}_{F R}$, the percentage of validating areas pixels in the very high class is slightly lower, and ranges from $48.14 \%$ (equal intervals method) to $80.54 \%$ (geometrical interval method) (tables 3 and 4$)$.

The data used for the ROC curve consists of the number of pixels corresponding to torrentiality phenomena areas, and of the values of the two indices: $\mathrm{FFPI}_{W o E}$ and $\mathrm{FFPI}_{F R}$. The curve was designed for both training and validating areas. This curve is used for highlighting the connection between prediction (FFPI values) and response (pixels with presence or absence of torrentiality phenomena). In the present case, the analysis only uses pixels of torrentiality phenomena areas
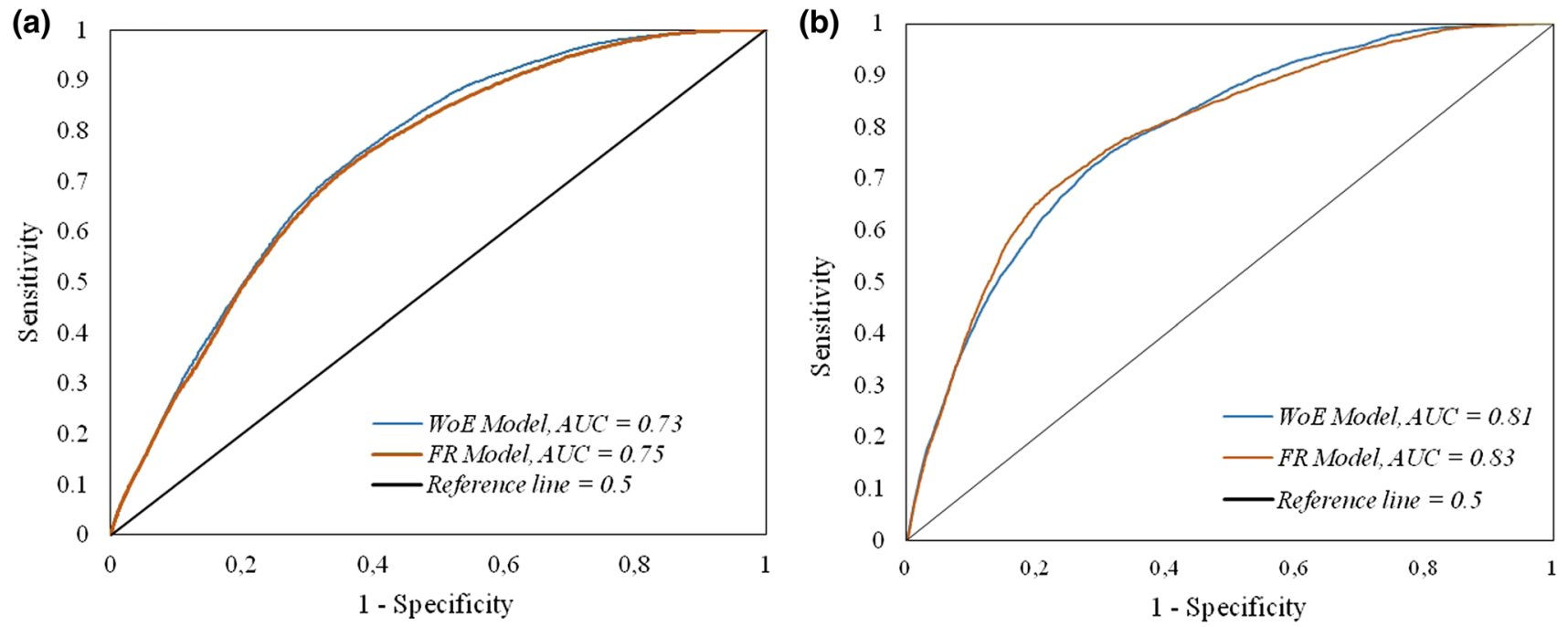

Figure 8. ROC curves with associated AUC values computed from (a) training samples and (b) validation samples. 
processed for model testing. The ROC curve is twodimensional, with $\mathrm{Y}$ axis for sensitivity and $\mathrm{X}$ axis for specificity. The model's efficiency lies in the area under the curve (AUC). Its value is subunitary, and the closer it gets to 1 , the better the model is (Pallant 2013).

In the case of the ROC curve designed for the training area sample, it can be noticed that the two applied methods (weights-of-evidence and frequency ratio) have AUCs that exceed 0.7, which means that the methods have a good efficiency (figure 8a). For the ROC curve designed for the validating area sample, the AUC values exceed 0.8 for both models, showing a very good efficiency (figure $8 b$ ).

\section{Conclusions}

Identifying areas susceptible to flash-flood occurrence is an issue of high practical interest in order to mitigate the related risks. This paper presents a methodology for flash-flood potential assessment and mapping based on the GIS environment integration of nine run-off control factors and two statistical methods (weights-of-evidence and frequency ratio) in GIS environment. We consider that, compared to the FFPI method used in previous studies, which is based strictly on the GIS integration of some run-off control variables, this approach, which integrates two statistical methods, offers the possibility to obtain more credible and accurate results. Credibility is confirmed by the validation of results, which was performed by two methods: (i) analysis of the percent distribution of the number of pixels with torrentiality phenomena in the classes of the two indices computed for the two statistical methods $\left(\mathrm{FFPI}_{\mathrm{WoE}}\right.$ and $\mathrm{FFPI}_{\mathrm{FR}}$ ), and (ii) by plotting the ROC curve for training area and validating area pixel samples.

An attempt to evaluate the FFPI values within Bâsca Chiojdului catchment was carried out by Prăvălie and Costache (2014). In order to calculate the FFPI, the authors used the evaluation marks of the geographical factors and their overlay in GIS environment through map algebra. Since the applied methodology for both studies is different, the range values of FFPI are also different. In the Prăvălie and Costache (2014) study, the surfaces characterized by a high and very high values of FFPI cover approximately $28 \%$ from the entire Bâsca Chiojdului catchment, while in present study these values are specific for $39 \%$ in case of $\mathrm{FFPI}_{W o E}$ and $33 \%$ for $\mathrm{FFPI}_{F R}$. Although the percentages occupied by high and very high FFPI values are different in terms of two research works, these areas are approximately localized in the same zone, mainly in the central part of Bâsca Chiojdului catchment.

The methodology applied in the present study allowed us to identify areas with high and very high potential of accelerated run-off and flood occurrence in the Bâsca Chiojdului River catchment, which total more than a third of the catchment's area. Such areas are mainly located in the central sector of the catchment (in the upper sectors of sub-catchments Stâmnic, Zeletin and Bătrâneanca), in the vicinity of settlements Chiojdu and Starchiojd.

The methodology proposed in this paper could be applied in catchments for which no information/maps are available on flood susceptibility. The presence of areas with high and very high potential of accelerated run-off and flash-floods occurrence requires the local-level adoption of appropriate measures for related risks mitigation. Nevertheless, it should bear in mind that the results could be subjected to errors and uncertainties due to several factors such as: possible inaccuracies resulted in the digitization process of the areas with torrential phenomena; errors in the spatial representation of the geographical variables used in the calculation of FFPI values. Given the fact that only static elements from the topographical surface are used for the FFPI determination, this index gives a general idea about flash-flood potential for certain surfaces, therefore it is necessary to analyse many other information in real time (the amount of precipitation estimated by weather radar) during the flash-flood forecast activity.

\section{Acknowledgements}

Authors would like to thank the anonymous reviewers of the Journal of Earth System Science, for their critical and valuable comments that helped to bring the manuscript into its present form.

\section{References}

Arachchige R and Perera D J 2015 Mapping flash flood potential using GIS and the Flash Flood Potential Index (FFPI) in the Turtle River and Forest River watersheds in North Dakota. The University of North Dakota. 
Bonham-Carter G F 1994 Geographic information systems for geoscientists: Modeling with GIS; In: Computer methods in the geoscientists, Pergamon Press, New York, 13 398.

Ceru J 2012 Flash Flood Potential Index for Pennsylvania; Proceedings, 2012 ESRI Federal GIS Conference. http://proceedings.esri.com/library/userconf/feduc12/pa pers/user/JoeCeru.pdf.

Chendeş V 2011 Resursele de apă din Subcarpaii de la Curbură: evaluări geospaiale; Edit. Academiei Române, ISBN 978-973-27-2131-5.

Costache R 2014 Using GIS techniques for assessing lag time and concentration time in small river basins. Case study: Pecineaga River Basin, Romania; Geographia Technica 9(1) 31-38.

Costache R, Fontanine I and Corodescu E 2014 Assessment of surface runoff depth changes in Sărăel River basin, Romania using GIS techniques; Cent. Eur. J. Geosci. 6(3) 363-372.

Costache R, Pravalie R, Mitof I and Popescu C 2015 Flood vulnerability assessment in the low sector of Saratel Catchment. Case study: Joseni Village; Carpath. J. Earth. Environ. Sci. 10(1) 161-169.

Corsini A, Cervi F and Ronchetti F 2009 Weight of evidence and artificial neural networks for potential groundwater spring mapping: An application to the Mt. Modino area (Northern Apennines, Italy); Geomorphology 111(1) 79 87.

Dahal R K, Hasegawa S, Nonomura A, Yamanaka M, Masuda T and Nishino K 2008 GIS-based weights-ofevidence modelling of rainfall-induced landslides in small catchments for landslide susceptibility mapping; Environ. Geol.54 311-324.

DHI 2009 A modelling system for rivers and channels - Mike 11, Reference Manual.

Fontanine I E and Costache R 2013 The potential for water diffuse pollution with heavy metals in Arieş River Basin; Analele Stiintifice ale Universitatii "Alexandru Ioan Cuza" din Iasi-Seria Geografie 59(2) 59-72.

Fuchs S 2009 Susceptibility versus resilience to mountain hazards in Austria - paradigms of vulnerability revisited; Nat. Hazard. Earth. Syst. Sci. 9(2) 337-352.

Fuchs S, Spachinger K, Dorner W, Rochman J and Serrhini K 2009 Evaluating cartographic design in flood risk mapping; Environ. Hazard. 8(1) 52-70.

Fuchs S, Keiler M and Zischg A 2015 A spatiotemporal multihazard exposure assessment based on property data; Nat. Hazard Earth. Syst. Sci. 15(9) 2127-2142.

Godfrey A, Ciurean R L, van Westen C J, Kingma N C and Glade T 2015 Assessing vulnerability of buildings to hydro-meteorological hazards using an expert based approach - An application in Nehoiu Valley, Romania; Int. J. Disaster Risk Reduction 13 229-241.

Gonçalves P, Marafuz I and Gomes A 2015 Flood hazard, Santa Cruz do Bispo Sector, Leça River, Portugal: A methodological contribution to improve land use planning; J. Maps 11(5) 760-771.

Karagiorgos K, Thaler T, Heiser M, Hübl J and Fuchs S 2016a Integrated flash flood vulnerability assessment: Insights from East Attica, Greece; J. Hydrol. 541 553562.
Karagiorgos K, Thaler T, Hübl J, Maris F and Fuchs S 2016b Multi-vulnerability analysis for flash flood risk management; Nat. Hazards 82(1) 63-87.

Kayastha P, Dhital M R and De Smedt F 2012 Landslide susceptibility mapping using the weight of evidence method in the Tinau watershed, Nepal; Nat. Hazards 63(2) 479-498.

Kruzdlo R 2010 Flash Flood Potential Index for the Mount Holly Hydrologic Service 31 Area; http://www.state.n j.us/drbc/library/documents/Flood_Website/flood-warni ng/userforums/Krudzlo_NWS.pdf.

Kumar R and Anbalagan R 2015 Landslide susceptibility zonation in part of Tehri reservoir region using frequency ratio, fuzzy logic and GIS; J. Earth Syst. Sci.124(2) 431448.

IPCC 2014: Summary for policymakers; In: Climate Change 2014: Impacts, Adaptation, and Vulnerability. Part A: Global and Sectoral Aspects. Contribution of Working Group II to the Fifth Assessment Report of the Intergovernmental Panel on Climate Change, 32p, http:// ipcc-wg2.gov/AR5/report/.

Lee S and Choi J 2004 Landslide susceptibility mapping using GIS and the weight-of-evidence model; Int. J. Geogr. Inf. Sci. 18(8) 789-814.

Lee S and Pradhan B 2007 Landslide hazard mapping at Selangor, Malaysia using frequency ratio and logistic regression models; Landslides4 33-41.

Lee S and Sambath T 2006 Landslide susceptibility mapping in the Damrei Romel area, Cambodia using frequency ratio and logistic regression models; Environ. Geol. 50(6) 847-855.

Mărgărint M, Grozavu A and Patriche C 2013 Assessing the spatial variability of coefficients of landslide predictors in different regions of Romania using logistic regression; Nat. Hazard Earth. Syst. Sci.13(12) 3339-3355.

Meyer V, Kuhlicke C, Luther J, Fuchs S, Priest S, Dorner W, Serrhini K, Pardoe J, McCarthy S, Seidel J, Palka G, Unnerstall H, Viavattene C and Scheuer S 2012 Recommendations for the user-specific enhancement of flood maps; Nat. Hazard Earth. Syst. Sci. 12(5) 17011716 .

Minea G 2013 Assessment of the flash flood potential of Bâsca River Catchment (Romania) based on physiographic factors; Cent. Eur. J. Geosci. 5(3) 344-353.

Mohammady M, Pourghasemi H R and Pradhan B 2012 Landslide susceptibility mapping at Golestan Province, Iran: A comparison between frequency ratio, DempsterShafer, and weights-of-evidence models; J. Asian Earth Sci. 61 221-236.

National Engineering Handbook 2007, Chapter 7 - Hydrologic Soil Groups, United States Department of Agriculture - National Resources Conservation Service.

National Institute of Hydrology and Water Management (NIHWM) Romania 2015 Archive database, Bucharest.

Orthophotomaps 2008 National Agency for Cadastre and Land Registration (NACLR), Romania.

Pallant J 2013 SPSS survival manual; McGraw-Hill Education, London (UK).

Park S, Choi C, Kim B and Kim J 2013 Landslide susceptibility mapping using frequency ratio, analytic hierarchy process, logistic regression, and artificial neural network 
methods at the Inje area, Korea; Environ. Earth Sci. 68(5) 1443-1464.

Pișota I, Zaharia Liliana and Diaconu D 2010 Hidrologie (Ediția a II-a revizuită și adădugită); Editura Universitară București, București.

Poudyal C P, Chang C, Oh H J and Lee S 2010 Landslide susceptibility maps comparing frequency ratio and artificial neural networks: A case study from the Nepal Himalaya; Environ. Earth Sci. 61(5) 1049-1064.

Pourghasemi H R, Pradhan B, Gokceoglu C, Mohammadi M and Moradi H R 2013 Application of weights-ofevidence and certainty factor models and their comparison in landslide susceptibility mapping at Haraz watershed, Iran; Arab. J. Geosci. 6(7) 2351-2365.

Pradhan B, Oh H J and Buchroithner M 2010 Weights-ofevidence model applied to landslide susceptibility mapping in a tropical hilly area; Geomat. Nat. Haz. Risk 1(3) $199-223$.

Prăvălie R and Costache R 2013 The vulnerability of the territorial-administrative units to the hydrological phenomena of risk (flash-floods). Case study: The subcarpathian sector of Buzău Catchment; Analele Universităii din Oradea-Seria Geografie 23(1) 91-98.

Prăvălie R and Costache R 2014 The analysis of the susceptibility of the flash-floods' genesis in the area of the hydrographical basin of Bâsca Chiojdului river; Forum Geografic13(1) 39-49.

Regmi N R, Giardino J R and Vitek J D 2010 Modeling susceptibility to landslides using the weight of evidence approach: Western Colorado, USA; Geomorphology 115(1) 172-187.

Ruin I, Creutin J D, Anquetin S, Lutoff C 2008 Human exposure to flash floods - Relation between flood parameters and human vulnerability during a storm of September 2002 in southern France; J. Hydrol. 361(1) 199-213.

Smith G 2003 Flash flood potential: Determining the hydrologic response of FFMP basins to heavy rain by analyzing their physiographic characteristics; http://www.cbrfc. noaa.gov/papers/ffpwpap.pdf, 11p.

Špitalar M, Gourley J J, Lutoff C, Kirstetter P E, Brilly M and Carr N 2014 Analysis of flash flood parameters and human impacts in the US from 2006 to 2012; J. Hydrol. 519 863-870.

Corresponding editor: Subimal Ghosh
Teodor S and Matreata S 2011 A way of determining how small river basins of Somes river are susceptible to flashfloods; Carpath. J. Earth. Environ. 6(1) 89-98.

Terti G, Ruin I, Anquetin S and Gourley J J 2015 Dynamic vulnerability factors for impact-based flash flood prediction; Nat. Hazards 79(3) 1481-1497.

Van Westen C J, Montoya A L, Boerboom L G J and Badilla Coto E 2002 Multi-hazard risk assessment using GIS in urban areas: A case study for the city of Turrialba, Costa Rica; In: Proceedings of the regional workshop on best practices in disaster mitigation: Lessons learned from the Asian urban disaster mitigation program and other initiatives, 24-26 September 2002, Bali, Indonesia, pp. 120136.

Van Westen C J, Rengers N and Soeters R 2003 Use of geomorphological information in indirect landslide assessment; Nat. Hazards30(3) 399-419.

Yalcin A, Reis S, Aydinoglu A C and Yomralioglu T 2011 A GIS-based comparative study of frequency ratio, analytical hierarchy process, bivariate statistics and logistics regression methods for landslide susceptibility mapping in Trabzon, NE Turkey; Catena 85(3) 274-287.

Yilmaz I 2009 Landslide susceptibility mapping using frequency ratio, logistic regression, artificial neural networks and their comparison: A case study from Kat landslides (Tokat-Turkey); Comput. Geosci. 35(6) 1125-1138.

Youssef A M, Pradhan B and Hassan A M 2011 Flash flood risk estimation along the St. Katherine road, southern Sinai, Egypt using GIS based morphometry and satellite imagery; Environ. Earth Sci. 62(3) 611-623.

Zaharia L, Minea G, Ioana-Toroimac G, Barbu R and Sârbu I 2012 Estimation of the areas with accelerated surface runoff in the upper Prahova watershed (Romanian Carpathians), Balwois, Republic of Macedonia.

Zaharia L, Costache R, Prăvălie R and Minea G 2015 Assessment and mapping of flood potential in the Slănic catchment in Romania; J. Earth Syst. Sci.124(6) 13111324.

Zogg J and Deitsch K 2013 The Flash Flood Potential Index at WFO Des Moines, Iowa; National Weather Service working paper, http://www.crh.noaa.gov/images/dmx/ hydro/FFPI/FFPI_WriteUp.pdf 